EFFICINT

\title{
Credit Risk Determinants in Indonesia
}

\author{
Amin Yusuf Efendi ${ }^{凶}$ \\ Jurusan Ekonomi Pembangunan, Fakultas Ekonomi, Universitas Negeri Semarang
}

Permalink/DOI: https://doi.org/10.15294/efficient.vii2.30153

Received: January 2018 ; Accepted: March 2018; Published: Juny 2018

\begin{abstract}
Credit is the main business of the banking industry, therefore, in running the business, the bank is always overshadowed by the credit risk the which can be determined by the ratio of non-performing loans (NPL). The development of technology, finance digital brings the outside could impact on the financial industry both positive and negative. The purpose of this study was to analyze the interest rate, inflation, exchange rates, gross domestic product (GDP), a dummy finance digitalization policies in the long term and the short term of the non-performing loan (NPL) of conventional commercial banks in Indonesia The analytical method used in this research is-EG Error Correction Model (ECM), The Data used in this research is secondary quarterly time series data from the 20o8 quarter 1-2017 4. The time series of data are not stationar Often that can cause spurious regression results, the exact models used is-EG Error Correction Model (ECM), This models may explain the behavior of short-term and long-term. The results Showed in the short-term variable interest rates significanly to non-performing loans, while in the long-term variable interest rate, exchange rate, and GDP Significantly, non-performing loans.
\end{abstract}

Keywords: Macroeconomics, Industrial Production Index, Inflationa, Interest Rate, Exchange Rate, Credit.

\begin{abstract}
Abstrak
Kredit merupakan bisnis utama dari industri perbankan, oleh karena itu dalam menjalankan bisnisnya, bank selalu dibayangi oleh risiko kredit yang dapat diketahui melalui rasio non-performing loans (NPL). Perkembangan teknologi, menghadirkan digital finance yang membawa dampak luar bisa terhadap industri keuangan baik positif dan negatif. Tujuan dari penelitian ini adalah untuk menganalisis suku bunga, inflasi, kurs, produk domestik bruto (PDB) dummy kebijakan digitalisasi keuangan dalam jangka panjang dan jangka pendek terhadap non-performing loan (NPL) bank umum konvensional di Indonesia Metode analisis yang digunakan dalam penelitian ini adalah Error Correction Model-EG (ECM). Data yang digunakan dalam penelitian ini adalah data sekunder runtut waktu kuartalan dari 2008 kuartal 1 - 2017 kuartal 4. Data runtun waktu sering tidak stationar sehingga bisa menyebabkan hasil regresi palsu (spurious regression), Model yang tepat digunakan adalah Error Correction Model-EG (ECM), model ini dapat menjelaskan perilaku jangka pendek dan jangka panjang. Hasil penelitian menunjukkan dalam jangka pendek variabel suku bunga berpengaruh secara signifikan terhadap non performing loan, sedangkan dalam jangka panjang variabel suku bunga, kurs, dan PDB berpengaruh secara signifikan terhadap non perfoming loan.
\end{abstract}

\section{Kata Kunci: Ekonomi Makro, Indeks Produksi Industri, Inflasi, Suku Bunga, Nilai Tukar, Kredit.}

How to Cite: Efendi, A. (2018). Credit Risk Determinants in Indonesia. EFFICIENT Indonesian Journal of Development Economics, 1(2), 106-115. https://doi.org/10.15294/efficient.vii2.30153

(c) 2019 Semarang State University. All rights reserved

\footnotetext{
Alamat Korespondensi :

Alamat: Gedung L2 Lantai 2 FE Unnes

Kampus Sekaran, Gunungpati, Semarang, 50229

E-mail : aminyusuf@gmail.com
}

ISSN 


\section{INTRODUCTION}

Credit is one form of financing provided by banks. Bank in lending is always faced with various risks (Arofu, 2017), One of the risks faced is the high ratio of non-performing loans, the greater the NPL ratio, the level of the bank's health will get worse and have an impact on potential bank failures will be greater and vice versa, non-performing loan is calculated according to the formula, the number of loans classified noncurrent divided by total outstanding loans. (Firman, 2014)

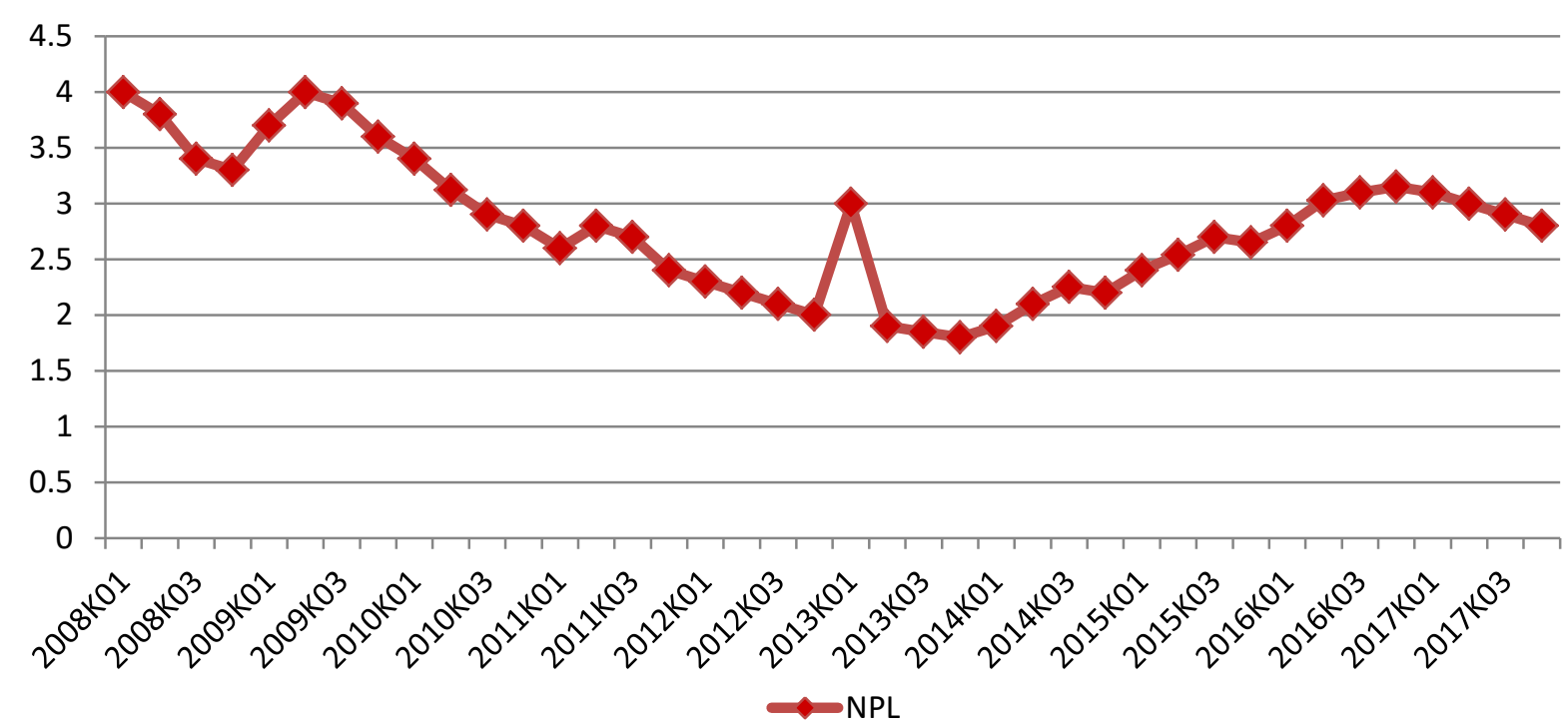

Figure 1. Non-Performing Loans (Percent) in Period 2008 Quartery Quarter 1-2017 Fourth Quarter Source: Bank Indonesia and the Financial Services Authority in Banking Statistics Indonesia (processed)2018.

Based on Figure 1.2 in the period 2008 Quarter 1-2017 fourth quarter non-performing loan levels fluctuated. In general, the movement of NPLs tend to the upside. The development of the macroeconomy experienced many shifts as the development of information and communication technology. The rapid development of information and communication technology is able to change the pattern and behavior, including conduct of business and economics. The entry of information and communication technology (ICT) in the economy is often referred to as the digital economy, according to Bank Indonesia (2015) only $36 \%$ of the total population in
Indonesia who have access to formal financial institutions. The implications of the development of information and communication technology as well as the many people who do not have access to financial services is the integration of information and communication technology with the financial sector.

The launch program of savings and Branchless Banking in 2013 by Bank Indonesia to early commencement of digitization policies in the financial sector, the launch of the Financial Service Without Office (Smart Code) by the FSA that when it took over the supervision function of the Bank of Bank 
Indonesia. The next phase of $\mathrm{BI}$ issued Circular No. 16/11 / DKSP on electronic money and BI Circular Letter No. 16/12 / DPAU on the Implementation of the Financial Services Digital (Zahirudin, 2015),

Digital Financial Services (LKD) is a merger of the provision of financial services and payments are submitted and managed using mobile technology or web technologies and network agent(Herdiana, 2014), Products from LKD such as mobile payment (m- payment), mobile banking (m-banking), internet banking and electronic money (emoney). Digital Finance to facilitate the public to access the services of financial institutions but on the other also carries the risk if it is not supported by valid data. In terms of credit fraud lot of credit, less precise in lending, and the increase of bad debts. According to Shingjergji (2013); Tanasković \& Jandric (2015); Bozdo \& Kripa (2015); Ginting (2016) NPL rise much influenced by macroeconomic factors.

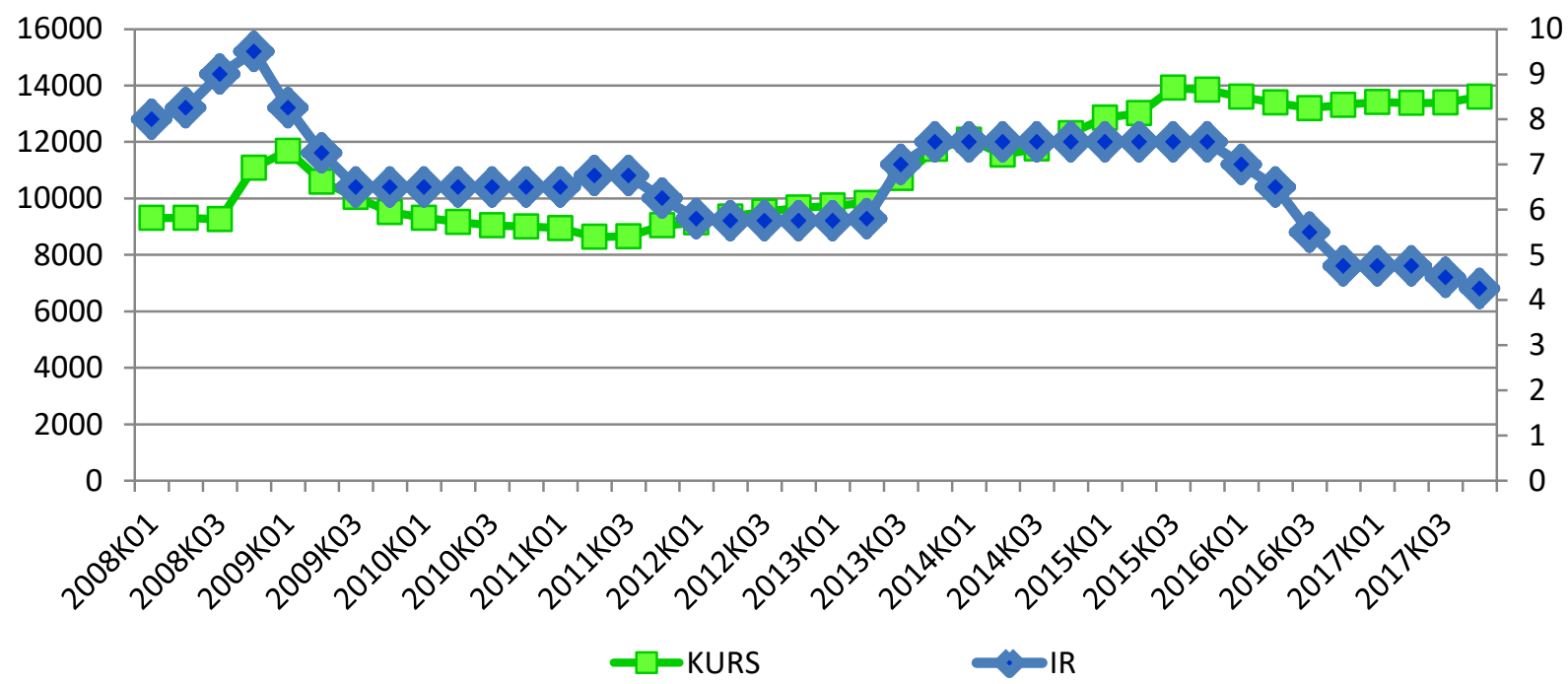

Figure 2. Exchange Rate / US Dollar (IDR) and Interest Rates (Percent) in Period 2008 Quartery Quarter 1-2017 Q4

Source: Bank Indonesia and the Financial Services Authority in Banking Statistics Indonesia (processed) 2018

In Figure 1.2 the exchange rate (USD / IDR) as a whole experienced an upward trend from 2008 Q1 amounted to Rp. 9303,5- / USD in 2017 Q4 amounted Rp.13.604,5, - / USD. In 2016 Q1 - Q3 2016 exchange rate decreased from Rp.13.6oo, - / USD amounted Rp.13.199,5, - / USD. But at the same time frame it is inversely proportional to the state of nonperforming loans (see figure 1.1), which showed an increase in the same period. Exchange rate appreciation describe the improving economic conditions but the conditions of nonperforming loans have increased.

Judging from Figure $\mathbf{1 . 2}$ can be seen that the interest rate in the quarter of 2008 . Quarter 1-2017 Q4 tends to fluctuate, but viewed as a whole experienced a downward trend. In 2008 the 3 - Quarter 2009 Q2 interest 
rate gradually declined from $9 \%-7.25 \%$, but in the same time frame it is inversely proportional to the state of non-performing loans that show an increase in this period (see figure 1). The condition was repeated in 2016
Q1 - 2016 Q4 where the interest rate gradually declined from $7 \%-4.75 \%$ but the level of nonperforming loans actually increased (see figure 1).

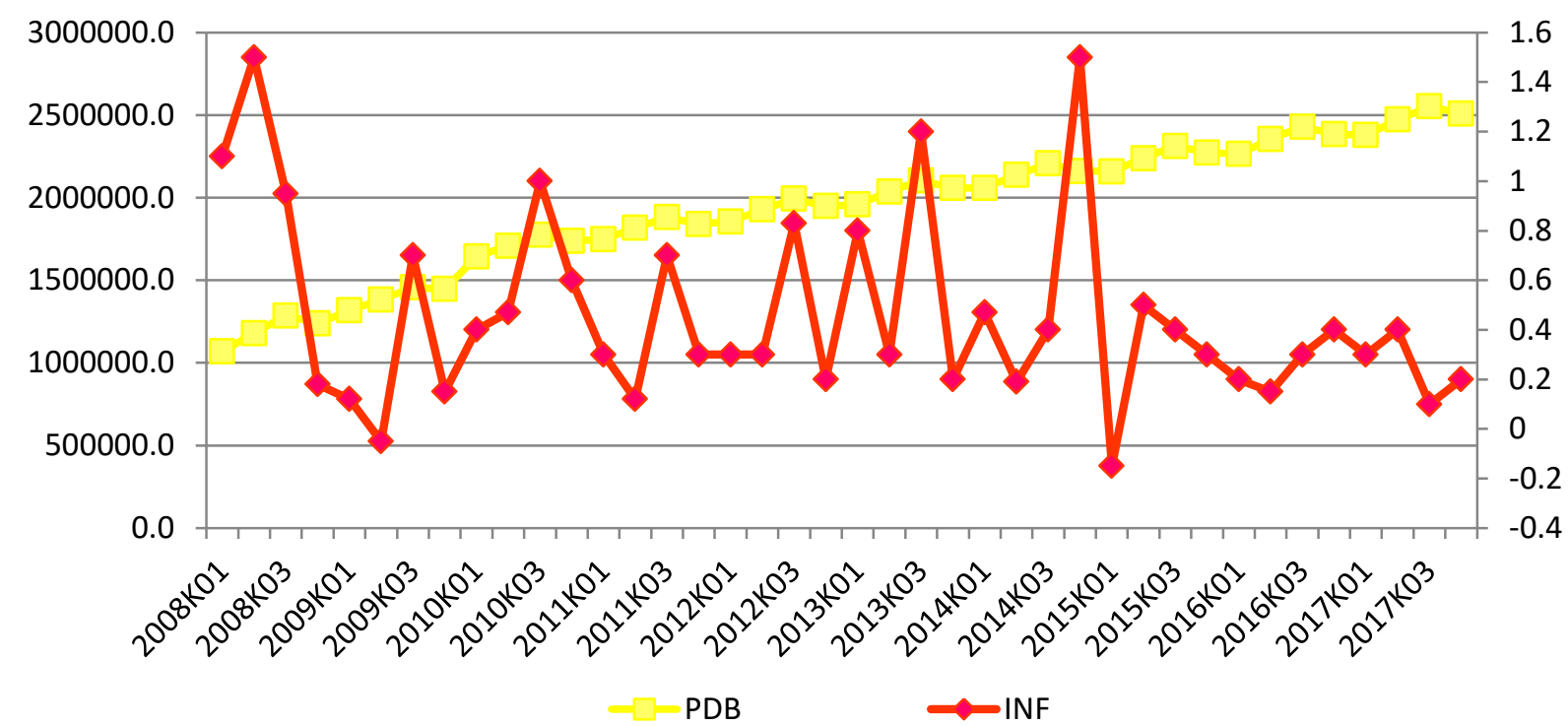

Figure 3. Inflation (Percent) and Gross Domestic Product (GDP quarter 2008 Period Quarter 12017 Q4)

Source: National Statistics (processed) 2018

Inflation in the period of 2008 Quarter 12017 Q4 fluctuate, but when viewed as a whole experienced a decrease trend inflation. In 2008 the upward trend of inflation experienced until at its peak in the 2nd quarter which touched $1.5 \%$ as a result of the financial crisis that hit the world. after 2008 Q2 economic conditions began gradually improved with the decline in inflation. Since 2014 Quarter 4-2015 Q3 inflation gradually declined from $1.5 \%-0.3 \%$, but the level of nonperforming loans actually increased during that time (see figure 1.1). The fall in the inflation rate indicates improvements in the economy by increasing purchasing power and further reduce the burden of debtors to repay their loans. Gross Domestic Product (GDP) in the period 2008 Quarter 1-2017 $\mathrm{Q}_{4}$, as a whole experienced a rising trend. In $2008 \mathrm{Q}_{4}$ GDP gradually began to increase from Rp. 1238754.5, - until 2009 Q2 Rp. 1383350.5, - but in the same time non-performing loans experienced a rise of $3.3 \%-4 \%$ (see figure 1.1). A similar thing happened in 2016 Q1 to $2016 \mathrm{Q}_{4}$ where GDP showed a trend increase from Rp. 2.26468 million, - to Rp. 2.385..244, - but the level of non-performing loans experienced a rise of $2.8 \%-3.15 \%$ (see figure 1.1). The rise in GDP indicates improvements in the economy by increasing public revenue and increase the ability to repay the loan.

Based on these data we can see that on a quarterly basis in the year 2008-2017 interest 
rates, inflation experienced a decline trand, although exchange rate depreciated but still looks stable and GDP shows trand increased. This shows that the economy can be said to be improving. There is a gap phenomenon here, where non-performing laon occur trand increase (see figure 1.1). It is counterproductive when viewed macroeconomic indicates improving conditions, improving economic conditions indicate the economy running smoothly, which means that people and companies can pay back the loan to the bank with the better so as to reduce the ratio of non-performing laon. Namnun according to Figure 1.1 NPL even increased when the economy goes toward the better.

This study aimed to analyze the relationship between macroeconomic variables and their influence on the bank's non-performing laon common in Indonesia.

\section{RESEARCH METHODS}

This study uses a quantitative approach, according Sugiyono (2010) emphasizes the quantitative approach to the dates in the form of numbers or qualitative data diangkakan. Quantitative methods will be acquired significance significant group differences or relationships between the variables studied. The data used in this research is secondary data time series with the first quarter of the period 2008 to 2017 4th quarter were sourced from various agencies related publications, such as Bank Indonesia, the Financial Services Authority, the Central Statistics Agency (BPS).

The method of data analysis is a research method used in analyzing the data. The steps are performed in the data analysis in this study is the correlation analysis method Error (Error
Correction Model / ECM). Analysis tools using a computer program Econometric Views 9.0 (Eviews). According toBasuki (2016) method Error Correcttion Model (ECM) as a means of econometric calculations and is also used analisisi descriptive method aims to identify long-term and -term due to the presence of cointegration among variables. The model will be used as a research model that is encapsulated in the ECM-EG as follows :

Long-term models are:

$$
\begin{aligned}
& \text { NPLt }=\alpha_{0}+\alpha_{1} \text { IRT }+\alpha_{2} \text { INFt }+\alpha_{3} \text { KURSt- } \\
& \alpha 4 \mathrm{PDBt}+\alpha_{4} \mathrm{Dt}
\end{aligned}
$$

Engle Granger Error Correction Model :

$$
\begin{aligned}
& \Delta \mathrm{NPLt}=\alpha_{0}+\alpha_{1} \Delta \mathrm{IRt}+\alpha_{2} \Delta \mathrm{INFt}+ \\
& \alpha_{3} \Delta \text { KURSt }-\alpha 4 \Delta \mathrm{PDBt}+\alpha_{4} \Delta \mathrm{Dt} \\
& + \text { ECTt-1 }
\end{aligned}
$$

Information:

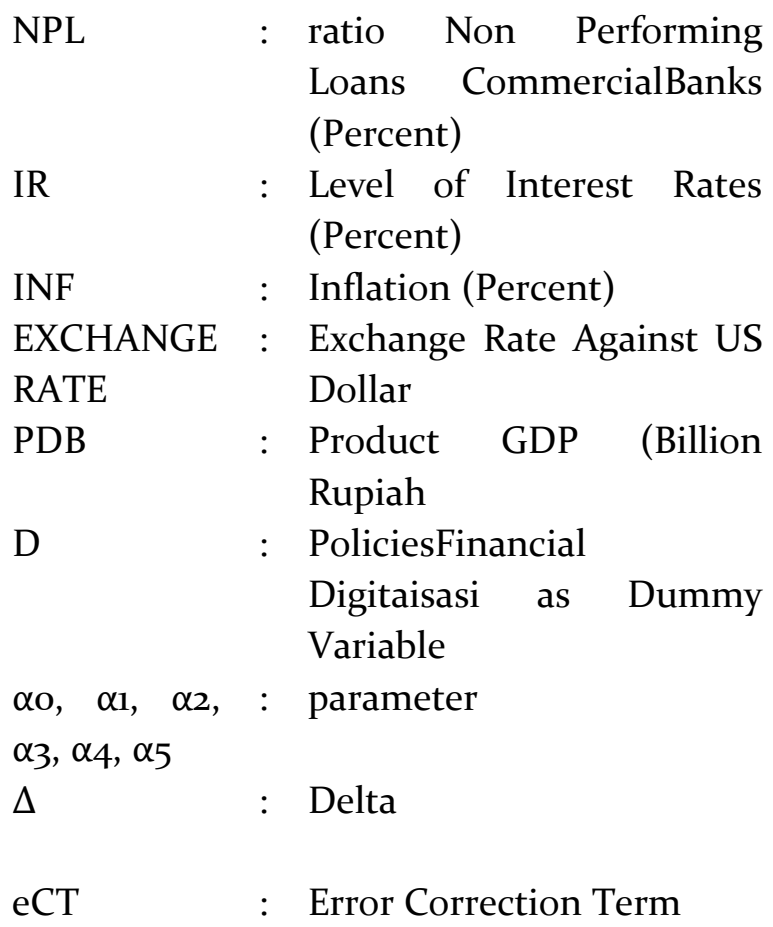




\section{RESULTS AND DISCUSSION}

Table 1. Stationaritas Test Data In Diferensi First Level

\begin{tabular}{lllllll}
\hline \multirow{2}{*}{ variables } & \multirow{2}{*}{ ADF-Test } & \multicolumn{3}{c}{ ADF McKinnon } & \multirow{2}{*}{ Probabilitas } & Informatio \\
\cline { 3 - 5 } & & \multicolumn{1}{c}{$\mathbf{1} \%$} & $5 \%$ & \multicolumn{1}{c}{$10 \%$} & \\
\hline NPL & $-7,157,744$ & $-3,615,588$ & $-2,941,145$ & $-2,609,066$ & 0.0000 & Stationar \\
IR & $-3,474,016$ & $-3,615,588$ & $-2,941,145$ & $-2,609,066$ & 0.0143 & Stationar \\
INF & $-5,811,151$ & -3.6329 & $-2,948,404$ & $-2,612,874$ & 0.0000 & Stationar \\
EXCHANGE & $-4,398,636$ & $-3,615,588$ & $-2,941,145$ & $-2,609,066$ & 0.0012 & Stationar \\
RATE & -4.30626 & $-3,661,661$ & $-2,960,411$ & -2.61916 & 0.0020 & Stationar \\
PDB & & & & & \\
\hline
\end{tabular}

Source: Processed Eviews 9.0

Based on table 1 note that all significant variables on the level 1 st different-trend andintercept, the probability value of each variable NPLs 0.0000 , 0.0143 annual interest rate, inflation of 0.0000 , the exchange rate as big as GDP amounted to 0.0143 and 0.0020 , which means $\alpha$ is smaller than $5 \%$.

Table 2. Long Term Regression Results

\begin{tabular}{lllll}
\hline variable & Coefficient & Std. Error & T-Statistic & probability \\
\hline C & 5649081 & 1451899 & 3890823 & 0.0004 \\
IR & -0.337305 & 0.078642 & $-4,289,123$ & 0.0001 \\
INF & 0.160525 & 0.163641 & 0.980959 & 0.3335 \\
EXCHANGE RATE & 0.000370 & $7.45 \mathrm{E}-05$ & 4960561 & 0.0000 \\
PDB & $-2.40 \mathrm{E}-06$ & $3.94 \mathrm{E}-07$ & $-6,103,883$ & 0.0000 \\
DUMMY & -0.222347 & 0.373038 & -0.596044 & 0.5551 \\
R-squared & 0.728666 & & & \\
Adjusted R-squared & 0.688764 & & & \\
F-statistic & 1826139 & & & \\
Prob (F-statistic) & 0.000000 & & & \\
Durbin-Watson stat & 1147312 & & & \\
\hline
\end{tabular}

Source: Processed Eviews 9.0

* Significant at the level $\alpha=5 \%$

The results of long-term estimates in Table 2. model can be written as follows:

$$
\begin{aligned}
\text { NPLt }= & 5.649081-.3375 \text { Irt }+0,16 \mathrm{INFt}+ \\
& 0,000370 \text { KURSt }- \\
& 0,0000024 \text { PDBt-0,22Dt }+\mu \mathrm{t}
\end{aligned}
$$

The results of short-term estimates in Table 3. model can be written as follows:

$$
\begin{aligned}
\Delta \mathrm{NPLt}= & -0,031297-0,254 \Delta \mathrm{IRt} \\
& +0.148 \Delta \mathrm{INFt}+0.0000944 \Delta \mathrm{KU} \\
& \text { RSt-0.000000608 } \Delta \mathrm{PDB}- \\
& 0.206 \Delta \mathrm{Dt}-0.544 \mathrm{ECTt}-1+\mu \mathrm{t}
\end{aligned}
$$


Table 3. Regression Results Short Term Error Correction Model-EG

\begin{tabular}{lllll}
\hline \multicolumn{1}{c}{ Variable } & \multicolumn{1}{c}{ Coefficient } & \multicolumn{1}{c}{ Std. Error } & \multicolumn{1}{c}{ T-Statistic } & \multicolumn{1}{c}{ Probability } \\
\hline C & -0.031297 & 0.055459 & -0.564325 & 0.5765 \\
D (IR) & -0.254185 & 0.107215 & $-2,370,787$ & 0.0239 \\
D (INF) & 0.148429 & 0.084972 & 1746789 & 0.0903 \\
D (EXCHANGE) & $9.44 \mathrm{E}-05$ & $9.73 \mathrm{E}-05$ & 0.969707 & 0.3395 \\
D (GDP) & $-6.08 \mathrm{E}-07$ & $7.62 \mathrm{E}-07$ & -0.797982 & 0.4308 \\
DUMMY & -0.206543 & 0.316641 & -0.652293 & 0.5189 \\
ECT (-1) & -0.544573 & 0.131931 & $-4,127,711$ & 0.0002 \\
R-squared & 0.425779 & & & \\
Adjusted R-squared & 0.318113 & & & \\
F-statistic & 3954619 & & & \\
Prob (F-statistic) & 0.004536 & & & \\
Durbin-Watson stat & $\mathbf{2 2 5 3 3 5 2}$ & & & \\
\hline
\end{tabular}

Source: Processed Eviews 9.0

* Significant at the level $\alpha=5 \%$

Model ECM-EG is said to be valid if the error correction coefficient signs (ECT) is negative and statistically significant (Widarjono 2009). Based on estimates in Table 1.3 in mind that the ECT significant at $\alpha=5 \%$ with a coefficient value of-0.544573 which means that the model ECM-EG is a legitimate use and able to correct imbalances in the short term into long-term balance of $54.4 \%$.

Influence the variable interest rate on short-term estimates have a coefficient of 0.254185 meaning that any reduction in interest rates by $1 \%$ would cause an increase in NPLso.254185\%, Furthermore, interest rates significant negative effect in the short term to NPL it is shown on the probability value $<$ critical limit $(0.0239<0.05)$. or Ho received, is in line with research (Saba, Kouser, \& Azeem, 2012); Bekhet \& Eletter (2014), The estimation results of short-term interest rates significantly affect non-performing loans, the negative effect can be interpreted in case of interest rate cuts, the public and business people tend more to borrow money in the bank because the interest rate on the pay is not low, thus lending more and potentially increase credit risk.

Variable interest rates on long-term estimates have a coefficient of -0.337305 meaning that any reduction in interest rates of $1 \%$ would cause a rise in NPLs amounting to 0,337 305\%, Furthermore,Interest Rates significant negative effect in the long term to NPL it is shown on the probability value $<$ critical limit (0.0001 <0.05).or Ho be accepted. In the long term the interest rate cuts to spur credit growth and further drive the economy, but the decline in interest rates continuously increasing number of credit could trigger uncontrollable and lead to greater risk of bad loans.

Variables influence inflation in the short term estimates have a coefficient of 0.148429 means that any increase in inflation by $1 \%$ 
would cause an increase in NPLso.148429\%, Furthermore, inflation probability values critical limit (0.0903> 0.05) so that it can be concluded in the short-term inflation variable has no effect on the NPL. or Hobe accepted. Variable inflation in the long-term estimates have a coefficient of 0.160525 means that any increase in inflation by $1 \%$ would cause an increase in NPLso.160525\%, Furthermore, inflation probability value> critical limit (0.335> 0.05) so that it can be concluded in the long-term inflation variable has no effect on the NPL. or Hobe accepted. The results of this study support (Firman, 2014).

The estimation results indicate a longterm short-term inflation does not affect the NPL ratio, despite inflation variable has a high fluctuation but it is only temporary as it approached the religious holiday, the moment of beginning and end of the year and the inflation rate is mostly caused by food. The rise of high inflation followed by a variety of market control policies by the government so that the inflation rate back controlled by the government and does not affect bad credit.

The effect of variable rate on short-term estimates have a coefficient value of 0.0000944 means that any increase in inflation by $1 \%$ would cause an increase in NPLs by o.00o0944\%, Furthermore, rate probability value> critical limit $(0.3395>0.05)$ so that it can be concluded in the short-term variable rate has no effect on the NPL. or Hobe accepted. The variable rate on a long-term estimate has a coefficient of 0.000370 means that any increase in inflation by $1 \%$ would cause an increase in NPLso.00037\%, Furthermore, rate probability value <critical limit $(0.0000<0.05)$ so that it can be concluded variable rate long-term significant effect on the NPL. or Hibe accepted. The results of this study supportShingjergii (2013); Tanasković \& Jandric (2015).

The exchange rate in the short term does not burden the public and the business community in carrying out activities using foreign exchange transactions. But, in the long term depreciation of the rupiah in the long term can shake the world of business because the majority of the raw materials are imported so the more burdensome the business world in paying off debt obligations and may increase credit risk. GDP variable effect on short-term estimates have a coefficient of-o.0ooooo6o8 meaning that any increase GDP by $1 \%$ would cause a decrease in NPLs in Indonesia amounted to $0.000000608 \%$. Furthermore, GDP probability value> critical limit (0.4308> 0.05 )It can be concluded GDP variable in the short term has no effect on NPLs in Indonesia. or Hobe accepted. Variable GDP in the longterm estimates have a coefficient of-o.ooooo24 meaning that any increase GDP by $1 \%$ would cause a decrease in NPLs in Indonesia amounted to $0.0000024 \%$. Furthermore, GDP probability value <critical limit (o.oooo $<0.05$ )It can be concluded variables of GDP in the long term significant negative effect on NPLs in Indonesia. or H1 received, is in line with research Ekanayake et al. (2013);Adicondro \& Pangestuti (2015);Mensah \& Adjei (2015).

If there descend revenue in the short term has little impact on financing problems. So in the short term revenue is not significant in influencing credit risk. But, in the long termdecrease in public income may increase credit risk, this is in accordance with the theory of the business cycle in which each occurred penuruanan business cycle will have 
an impact on the economy and may increase credit risk.

Financial Digitization policy variables influence on short-term estimates have a coefficient of-0.206543 negative sign, Furthermore, Dummy probability value> critical limit (0.5189>0.05) It can be concluded financial digitization policy variable in the short term has no effect on NPLs in Indonesia or Hobe accepted. Financial Digitization policy variables on the estimation of the long-term has a coefficient of-0.222347 are negative with probability> critical limit (0.555> 0.05). It can be concluded financial digitization policy variable in the long run no effect on NPLs in Indonesia. or Ho be accepted.

Digitization finance in the short term and the long term due to less influence is not yet even technology infrastructure, communication and information are still concentrated in large cities, the low abiding by the public related to the use of mobile technology, improvement of governance data base.(Bank Indonesia, 2015)

\section{CONCLUSION}

Based on the results of research and discussion, it can be seen partially in long-term interest rates and exchange rates positive and significant impact on non-performing loans, GDP is negative and significant effect on nonperforming loans, while inflation and the policy of digitizing finance has no effect on non-performing loans, In the short-term interest rates and a significant negative effect on non-performing loans, while the exchange rate, inflation, GDP, and the policy has no effect on non-performing loans.

Increasing economic growth and push the economy higher quality of government should be to encourage the business community in order to improve the quality of the output through serngkaian policies such as control of competitive interest rates for the business world, inflation control, and control of the exchange rate and continue to encourage the expansion of exports to countries potential such as Africa, Latin America and Eastern European countries. In an effort to improve access to government financial institutions need to improve the digital infrastructure into the countryside so that the wider community can obtain financial services through digitization.

\section{REFERENCE}

Ali, A., \& Daly, K. (2010). Macroeconomic determinants of credit risk: Recent evidence from a cross country study. International Review of Financial Analysis, 19(3), 165-171. https://doi.org/10.1016/j.irfa.2010.03.001

Arofu, L. (2017). Faktor-faktor yang mempengaruhi Non Performing Loans. Journal Dinamika Manajemen, Universitas Negeri Semarang.

Bank Indonesia (2015). Financial Technology (Perkembangan dan Respon Kebijakan Bank Indonesia), Puslitbang Bank indonesia 1-18.

Beck, R., Jakubik, P., \& Piloiu, A. (2015). Key Determinants of Non-performing Loans: New Evidence from a Global Sample. Open Economies Review, 26(3), 525-550. https://doi.org/10.1007/s11079-015-9358-8

Bozdo, A., \& Kripa, E. (2015). The Impact of MacroEconomic Factors on Non-Performing Loans in 
Albania. Academic Journal of Interdisciplinary Studies, 4(3), https://doi.org/10.5901/ajis.2015.v4n3s1p534

Chaibi, H., \& Ftiti, Z. (2015). Credit risk determinants: Evidence from a cross-country study. Research in International Business and Finance, 33, 1-16. https://doi.org/10.1016/j.ribaf.2014.06.001

Firmansyah, I. (2014). Determinant of Non Performing Loan: the Case of Islamic Bank in Indonesia. Buletin Ekonomi Moneter Dan Perbankan, 17(2), 241-258. https://doi.org/10.21098/bemp.v17i2.51

Ghosh, A. (2015). Banking-industry specific and regional economic determinants of non-performing loans: Evidence from US states. Journal of Financial Stability, 20, 93-104. https://doi.org/10.1016/j.jfs.2015.08.004

Ginting, A. M. (2016). Pengaruh Makroekonomi Terhadap Non Performing loan (NPL) Perbankan ( The Influence of Macroeconomic Factor to Non Performing Loan ( NPL ) Banks ), Journal Ekonomi dan Bisnis 159-170.

Herdiana, D. (2014). Digital Financial Services (Layanan Keuangan Digital): Peluang dan Kemungkinan Penerapannya di Program KOTAKU, Buletin Ekonomi dan Perbankan 1-20.

Kabir, M. N., Worthington, A., \& Gupta, R. (2015). Comparative credit risk in Islamic and conventional bank. Pacific Basin Finance Journal,
34,

327-353.

https://doi.org/10.1016/j.pacfin.2015.06.001

Mensah, F. A., \& Adjei, A. B. (2015). Determinants of nonperforming loans in Ghana banking industry. International Journal of Computational Economics and Econometrics, 5(1), 35. https://doi.org/10.1504/IJCEE.2015.066207

Nikolaidou, E., \& Vogiazas, S. (2017). Credit risk determinants in Sub-Saharan banking systems: Evidence from five countries and lessons learnt from Central East and South East European countries. Journal of Advanced Research, 7(1), 5263. https://doi.org/10.1016/j.rdf.2017.01.003

Saba, I., Kouser, R., \& Azeem, M. (2012). Determinants of Non Performing Loans: Case of US Banking Sector. The Romanian Economic Journal, 15(January), 141-152.

Sousa, M. R., Gama, J., \& Brandão, E. (2016). A new dynamic modeling framework for credit risk assessment. Expert Systems with Applications, 45, 341-351. https://doi.org/10.1016/j.eswa.2015.09.055

Shingjergji, A. (2013). The Impact of Macroeconomic Variables on the Non Performing Loans in the Albanian Banking System During 2005 - 2012. Academic Journal of Interdisciplinary Studies, 2(9),

335-339. https://doi.org/10.5901/ajis.2013.v2n9p335

Zahirudin, I. A. (2015). Probank Membangun Perbankan Profesional. Buletin Perbankan Indonesia, pp. 1-17 